\title{
Analisis Pengenaan Bea Perolehan Hak Atas Tanah Dan Bangunan Dalam Proses Jual Beli Tanah Dan Bangunan Di Kabupaten Kebumen
}

\author{
Adimas Wahyu Widayat, S.H.
}

\begin{abstract}
Problems in this study, first, first, how the collection of the Tax on Acquisition of Land and Building in the process of buying and selling land and buildings in Kebumen? Second, what the obstacles that arise in the collection fees for acquisition of land and buildings, and how the completion of the constraints that arise in the collection of the fees for acquisition of land and buildings in the process of buying and selling land and buildings in Kebumen? This type of research is empirical jurisdiction. The study concluded, first: the first, for collection of the Tax on Acquisition of Land and Building in the process of buying and selling land and buildings in Kebumen conducted den $r$ gan self-assessment system which gives credence to the taxpayer to compute, calculate, pay their own taxes ter ᄀhutang using BPHTB SSPD form obtained by the taxpayer of DPPKAD Kebumen. Second, constraints-constraints that arise in the collection of the Tax on Acquisition of Land and Buildings include a lack of socialization regarding the manner of payment of BPHTB to the community, the level of public awareness is still very limited to the obligation to pay taxes, dishonesty taxpayers to include the value of purchase and sale transactions deed of sale, the shortage of skilled personnel in DPPKAD and the constraints arising from the bank / cash office area.
\end{abstract}

Keywords: Purchase, Land, Buildings, Kebumen.

\begin{abstract}
Abstrak
Permasalahan dalam penelitian ini, pertama, bagaimana pelaksanaan pemungutan Bea Perolehan Hak Atas Tanah dan Bangunan dalam proses jual beli tanah dan bangunan di Kabupaten Kebumen? Kedua, kendala-kendala apa yang timbul dalam pelaksanaan pemungutan bea perolehan hak atas tanah dan bangunan serta bagaimana penyelesain terhadap kendala-kendala yang timbul dalam pelaksanaan pemungutan bea perolehan hak atas tanah dan bangunan dalam proses jual beli tanah dan bangunan di Kabupaten Kebumen? Jenis penelitian ini adalah yuridis empiris. Hasil penelitian menyimpulkan, pertama: pertama, pelaksanaan pemungutan Bea Perolehan Hak atas Tanah dan Bangunan dalam proses jual beli tanah dan bangunan di Kabupaten Kebumen dilaksanakan dengan sistem self assessment yang memberikan kepercayaan kepada Wajib Pajak untuk menghitung, memperhitungkan, membayar sendiri pajak yang terhutang dengan menggunakan formulir SSPD BPHTB yang diperoleh oleh Wajib Pajak dari DPPKAD Kabupaten Kebumen. Kedua, kendala-Kendala yang timbul dalam pelaksanaan pemungutan Bea Perolehan Hak atas Tanah dan Bangunan diantaranya kurangnya sosialisasi mengenai tata cara pembayaran BPHTB kepada masyarakat, tingkat kesadaran masyarakat yang masih sangat terbatas pada kewajiban pembayaran pajak, ketidakjujuran wajib pajak dalam mencantumkan nilai transaksi jual beli pada akta jual beli, kurangnya jumlah personil yang ahli di DPPKAD serta kendala yang timbul dari pihak bank/kantor kas daerah.
\end{abstract}

Kata kunci: Jual Beli, Tanah, Bangunan, Kebumen. 


\section{Pendahuluan}

Tanah merupakan kebutuhan hidup manusia yang mendasar. Manusia hidup, berkembang biak, serta melakukan aktivitas di atas tanah. Hampir semua kegiatan hidup manusia dan makhluk lainnya berhubungan dengan tanah. Tanah merupakan kebutuhan pokok bagi manusia yang harus dipenuhi, selain makanan dan pakaian.

Begitu berharganya tanah, sehingga manusia akan selalu berupaya untuk mendapatkannya, dari upaya membuka hutan atau ladang, membeli dari pemilik tanah yang mau menjual, melakukan tukar menukar, dan upaya-upaya lainnya. Perbuatan-perbuatan diatas mengakibatkan pemilikan dan hak penguasaan tanah beralih dari satu pihak kepada pihak lain. ${ }^{1}$

Peralihan hak atas tanah dan bangunan berkaitan erat dengan kepastian hukum dan ditandai oleh adanya bukti atas peralihan hak tersebut. Untuk memberikan kekuatan dan kepastian hukum pemilikan tanah dan bangunan setiap peralihan hak atas tanah dan atau bangunan harus dilakukan sesuai dengan hukum yang mengaturnya. Perolehan hak sebagai hasil peralihan hak harus dilakukan secara tertulis dengan akta yang dibuat oleh pejabat yang berwenang, serta wajib didaftarkan pada instansi yang berwenang, yaitu kantor pertanahan Kabupaten/Kota setempat. Dengan demikian, hak atas tanah dan bangunan secara sah ada pada pihak yang memperoleh hak tersebut dan dapat dipertahankan terhadap semua pihak. ${ }^{2}$

Pasal 2 ayat (1) Peraturan Pemerintah Nomor 37 Tahun 1998 Tentang Peraturan Jabatan Pejabat Pembuat Akta Tanah, Pasal 2 ayat (1) menyebutkan bahwa setiap perbuatan hukum peralihan hak atas tanah dan bangunan baru dapat dibuktikan apabila dibuat oleh PPAT sebagaimana tugas pokoknya adalah melaksanakan sebagian kegiatan pendaftaran tanah dengan membuat akta sebagai bukti telah dilakukannya perbuatan hukum tertentu mengenai hak atas tanah atau hak milik atas satuan rumah susun, yang akan dijadikan dasar bagi pendaftaran perubahan data pendaftaran tanah yang diakibatkan oleh perbuatan hukum itu.

Peralihan hak atas tanah dan bangunan menimbulkan adanya hak dan kewajiban bagi pihak yang mengalihkan maupun pihak yang menerima peralihan hak. Pemerintah telah mengatur dalam peraturan perundang-undangan yang berlaku, dimana setiap orang pribadi atau badan yang memperoleh hak atas tanah dan bangunan wajib membayar pajak bea perolehan hak atas tanah dan bangunan yang dikenal dengan nama BPHTB. Bea Perolehan Hak Atas Tanah

\footnotetext{
${ }^{1}$ Siahaan, Marihot Pahala, Bea Perolehan Hak atas Tanah dan Bangunan, Teori dan Praktik, Edisi Revisi, Rajawali Pers, Jakarta, 2003, hlm. 5.

${ }^{2}$ Ibid, hlm. 7
} 
dan Bangunan (BPHTB) merupakan salah satu sumber potensi pajak yang patut digali sesuai situasi dan kondisi perekonomian serta perkembangan pembangunan bangsa sekarang ini. ${ }^{3}$

Bea Perolehan Hak Atas Tanah dan Bangunan sebelum diberlakukannya UndangUndang Nomor 28 Tahun 2009 Tentang Pajak Daerah dan Retribusi Daerah merupakan pajak yang dipungut oleh pemerintah pusat. Dengan adanya era otonomi daerah dan sejak diundangkannya Undang-Undang Nomor 28 Tahun 2009 tentang Pajak Daerah dan Retribusi Daerah maka telah terjadi pembaruan di bidang pajak daerah. BPHTB menjadi pajak daerah yang dipungut oleh pemerintah daerah kabupaten/kota.

Adanya desentralisasi fiskal memungkinkan masing-masing daerah menentukan sumber-sumber penerimaan bagi daerahnya, sesuai dengan potensinya masing-masing. ${ }^{4}$ Kewenangan daerah dalam hal fiskal tersebut diwujudkan oleh daerah dengan memungut salah satu potensi pendapatan daerah yaitu berasal dari pajak daerah sebagaimana diatur dalam Undang-Undang Nomor 28 tahun 2009 tentang Pajak Daerah dan Retribusi Daerah. Undangundang tersebut mengamanatkan bahwa salah satu jenis pajak kabupaten/kota adalah Pajak Bea Perolehan Hal atas Tanah dan Bangunan (BPHTB), yang menggunakan Nilai Perolehan Objek Pajak (NPOP) sebagai dasar pengenaan pajak tersebut.

Proses peralihan hak atas tanah dan atau bangunan hanya dapat dilakukan apabila wajib pajak telah menyerahkan bukti setor pembayaran pajak. Hal ini ditegaskan dalam Pasal 91 ayat (1) Undang-undang Nomor 28 Tahun 2009 tentang Pajak Daerah dan Retribusi Daerah yang menyatakan :

"Pejabat Pembuat Akta Tanah/Notaris hanya dapat menandatangani akta pemindahan Hak atas Tanah dan/atau Bangunan setelah Wajib Pajak menyerahkan bukti pembayaran pajak".

Selanjutnya Pasal 91 ayat (1) Undang-undang Nomor 28 Tahun 2009 tentang Pajak Daerah dan Retribusi Daerah menyebutkan :

"Pejabat Pembuat Akta Tanah/Notaris dan kepala kantor yang membidangi pelayanan lelang negara, yang melanggar ketentuan sebagaimana dimaksud dalam Pasal 91 ayat (1) dan ayat (2) dikenakan sanksi administratif berupa denda sebesar Rp7.500.000,00 (tujuh juta lima ratus ribu rupiah) untuk setiap pelanggaran”.

\footnotetext{
${ }^{3}$ Ibid, hlm. 6
}

${ }^{4}$ Ismail, Tjip, Pengaturan Pajak Daerah di Indonesia, Penerbit Departemen Keuangan Republik Indonesia Badan Pengkajian Ekonomi Keuangan dan Kerjasama Internasional Pusat Evaluasi Pajak dan Retribusi Daerah, Jakarta, 2005, hlm. 12. 
Besarnya jumlah denda yang dikenakan kepada PPAT apabila melakukan pelanggaran terhadap ketentuan Pasal 91 ayat (1) Undang-undang Nomor 28 Tahun 2009, dirasa sangat memberatkan dan mengakibatkan PPAT dalam posisi yang sulit, karena kewajiban untuk membayar BPHTB itu sendiri sebenarnya adalah kewajiban dari wajib pajak yang memperoleh hak atas tanah dan atau bangunan. Hal ini yang menyebabkan PPAT terkadang membantu wajib pajak yang menjadi kliennya untuk menghitung pajak yang harus dibayar oleh wajib pajak, serta membantu untuk membayar dan melaporkan pajak BPHTB mereka.

Kabupaten Kebumen sebagai salah satu kabupaten di Indonesia yang melaksanakan pemungutan pajak BPHTB sebagai pajak daerah berdasarkan Undang-Undang Nomor 28 tahun 2009, merupakan salah satu kabupaten yang terletak di wilayah Provinsi Jawa Tengah. Kegiatan perekonomian di Kabupaten Kebumen dari tahun ke tahun terus mengalami peningkatan. Meningkatnya perekonomian di Kabupaten Kebumen mengakibatkan meningkat pula kebutuhan akan tanah sebagai lokasi untuk melakukan kegiatan ekonomi tersebut. Hal ini tentu mengakibatkan banyak terjadi peralihan hak atas tanah dan atau bangunan. Banyaknya peralihan hak atas tanah dan atau bangunan menjadi potensi yang cukup besar untuk dapat dimanfaatkan sebagai sumber pendapatan bagi daerah melalui pemungutan pajak Bea Perolehan Hak Atas Tanah dan Bangunan (BPHTB).

Melaksanakan ketentuan Undang-undang Nomor 28 Tahun 2009, Pemerintah Kabupaten Kebumen telah menerbitkan Peraturan Daerah Kabupaten Kebumen Nomor 18 Tahun 2010 tentang Bea Perolehan Hak atas Tanah dan Bangunan. Peraturan Daerah ini mengadopsi Undang-undang Nomor 28 Tahun 2009 yang memuat aturan-aturan khusus mengenai Bea Perolehan Hak atas Tanah dan Bangunan serta tata cara pelaksanaan pemungutannya di Kabupaten Kebumen.

Dinas Pendapatan Pengelolaan Keuangan dan Asset Daerah (DPPKAD) Kabupaten Kebumen sebagai koordinator pelaksanaan pemungutan pajak dan retribusi daerah mempunyai peranan yang sangat penting, sehingga dituntut untuk lebih objektif dan lebih menetapkan kinerjanya agar tugas dan tanggung jawabnya tersebut dapat dilaksanakan dengan sebenar-benarnya.

Pemungutan BPHTB sebagai pajak daerah dalam pelaksanannya melibatkan banyak pihak yang terkait seperti: Kantor Pertanahan, Notaris/Pejabat Pembuat Akta Tanah (PPAT), Bank, Pemerintahan Daerah, Pengadilan termasuk lembaga-lembaga yang ada di bawahnya. 
Pemerintah Kabupaten Kebumen dalam melaksanakan wewenang pemungutan BPHTB berdasarkan Peraturan Daerah Kabupaten Kebumen Nomor 18 Tahun 2010 banyak mengalami kendala dan hambatan di lapangan. Berbagai kendala dan hambatan yang ditemukan dilapangan antara lain berupa transaksi jual beli tanah dan bangunan yang dilakukan di bawah tangan, harga transaksi yang tidak diketahui secara pasti, kurangnya sumber daya manusia yang menguasai aturan teknis BPHTB serta tingkat kepatuhan masyarakat dalam membayar pajak yang masih rendah. Selain itu adanya kewajiban verifikasi dan validasi atas pembayaran BPHTB oleh wajib pajak menjadi masalah tersendiri bagi wajib pajak maupun Notaris/PPAT.

Verifikasi dan validasi merupakan prosedur penelitian Surat Setoran Pajak Daerah BPHTB (SSPD BPHTB) terkait kelengkapan dokumen dan kebenaran data objek pajak yang tercantum dalam SSPD BPHTB. Prosedur ini dilakukan setelah wajib pajak melakukan pembayaran BPHTB terutang. Jika semua kelengkapan dan kesesuaian data objek pajak terpenuhi maka fungsi pelayanan akan menandatangani SSPD BPHTB tersebut.

Adanya kewajiban untuk melakukan verifikasi dan validasi BPHTB mengakibatkan PPAT yang bertugas dan berwenang membuat akta, juga menghadapi hambatan-hambatan dalam menjalankan tugas dan kewenangannya tersebut. Sehingga menghambat pelayanan yang diberikan oleh PPAT kepada kliennya, yang mengakibatkan terlambatnya proses peralihan hak atas tanah yang seharusnya bisa lebih cepat dan selesai dalam waktu relatif lebih singkat.

Proses verifikasi dan validasi BPHTB untuk menentukan nilai transaksi suatu perbuatan hukum jual beli hak atas tanah dan atau bangunan oleh pemerintah Kabupaten Kebumen pada dasarnya sah menurut undang-undang, akan tetapi menyalahi esensi dari suatu perjanjian jual beli. Perbuatan hukum jual beli pada dasarnya adalah kesepakatan para pihak. Adanya verifikasi dan validasi mengenai nilai jual objek pajak BPHTB seolah-olah membuat perjanjian jual beli tersebut dibuat bukan karena adanya kesepakatan para pihak dalam menentukan nilai jual tanah akan tetapi karena paksaan dari pemerintah daerah.

\section{Rumusan Masalah}

Berdasarkan uraian yang dikemukakan dalam latar belakang tersebut, maka ada beberapa hal yang menjadi pokok permasalahan dalam penelitian ini, yaitu: pertama, bagaimana pelaksanaan pemungutan Bea Perolehan Hak Atas Tanah dan Bangunan dalam proses jual beli tanah dan bangunan di Kabupaten Kebumen? Kedua, kendala-kendala apa yang timbul dalam pelaksanaan pemungutan bea perolehan hak atas tanah dan bangunan 
serta bagaimana penyelesain terhadap kendala-kendala yang timbul dalam pelaksanaan pemungutan bea perolehan hak atas tanah dan bangunan dalam proses jual beli tanah dan bangunan di Kabupaten Kebumen?

\section{Tujuan Penelitian}

Tujuan yang hendak dicapai dalam penelitian ini adalah sebagai berikut : pertama, untuk mengetahui dan menganalisis pelaksanaan pungutan Bea Perolehan Hak Atas Tanah dan Bangunan dalam proses jual beli tanah dan bangunan di Kabupaten Kebumen. Kedua, kendala-kendala apa yang timbul dalam pelaksanaan pemungutan bea perolehan hak atas tanah dan bangunan serta bagaimana penyelesain terhadap kendala-kendala yang timbul dalam pelaksanaan pemungutan bea perolehan hak atas tanah dan bangunan dalam proses jual beli tanah dan bangunan di Kabupaten Kebumen?

\section{Metode Penelitian}

Metode pendekatan yang dipergunakan dalam membahas masalah penelitian ini adalah metode pendekatan yuridis empiris. Yuridis Empiris adalah sebuah metode penelitian hukum yang berupaya untuk melihat hukum dalam artian yang nyata atau dapat dikatakan melihat, meneliti, bagaimana bekerjanya hukum di masyarakat. ${ }^{5}$ Spesifikasi yang diperlukan dalam penelitian ini adalah deskriptif analitis. Suatu penulisan deskriptif analitis berusaha menggambarkan masalah hukum, sistem hukum dan mengkajinya atau menganalisisnya sesuai dengan kebutuhan dari penelitian bersangkutan. Deskriptif dalam arti bahwa penelitian ini bertujuan untuk menggambarkan secara menyeluruh dan sistematik mengenai pengenaan bea perolehan ha katas tanah dan bangunan dalam proses jual beli tanah dan bangunan. Sedangkan analitis berarti mengelompokkan, menghubungkan, membandingkan dan memberi makna aspek-aspek dalam pelaksanaan pemungutan bea perolehan hak atas tanah dan bangunan dalam prakteknya di Kabupaten Kebumen. Subjek dan Objek Penelitian ini adalah:

a. Pejabat Kantor Dinas Pendapatan Pengelolaan Keuangan dan Asset Daerah (DPPKAD) Kabupaten Kebumen.

b. Notaris - PPAT.

c. Pejabat Kantor Pertanahan Kabupaten Kebumen.

\footnotetext{
${ }^{5}$ Ibid, hlm. 14
} 
d. Para pihak yang melakukan pendaftaran peralihan hak atas tanah dan bangunan.

Subjek penelitian di atas dapat dibedakan sebagai :

a. Narasumber yaitu : Pejabat di Pejabat Kantor Dinas Pendapatan Pengelolaan Keuangan dan Asset Daerah (DPPKAD) Kabupaten Kebumen, Pejabat Kantor Pertanahan Kabupaten Kebumen serta Notaris dan Pejabat Pembuat Akta Tanah;

b. Responden yaitu : 6 orang yang melakukan pendaftaran jual beli hak atas tanah dan bangunan, yang dipilih secara non random sampling ${ }^{6}$, yaitu cara pengambilan sample di mana semua populasinya tidak mempunyai kesempatan yang sama untuk menjadi anggota sampel dari dua wilayah kedudukan Kantor Pertanahan di atas yang dipilih sebagai lokasi sampel penelitian.

Sedangkan yang menjadi objek permasalahan dalam penulisan ini adalah: ketentuan pemungutan Bea Perolehan Hak Atas Tanah dan Bangunan dalam proses jual beli tanah dan bangunan di Kabupaten Kebumen dan kepastian hukum akta jual beli yang dibuat oleh PPAT berkaitan dengan adanya kewajiban verifikasi dan validasi BPHTB oleh Pemerintah Kabupaten Kebumen. Data yang dipergunakan dalam penelitian ini, berupa data primer dan data sekunder. Adapun jenis dan sumber data yang dipergunakan dalam penelitian ini adalah sebagai berikut: a. Data Primer diperoleh dengan cara mengadakan penelitian lapangan dengan mengadakan wawancara secara langsung kepada narasumber dan informan yang telah ditetapkan sebelumnya; b. Data Sekunder. Data sekunder ini terdiri dari peraturan perundang-undangan, buku, makalah, majalah di bidang hukum, artikel dari internet yang berkaitan dengan penelitian, kamus, ensiklopedia serta bahan-bahan tulisan yang dapat dipergunakan untuk mendukung hasil penelitian.

Data yang berhasil dikumpulkan dalam penelitian tersebut (baik data primer maupun sekunder) akan dianalisis dengan menggunakan analisa kualitatif, artinya menguji data dengan konsep dan pendapat para ahli, peraturan perundang-undangan dan studi lapangan kemudian ditarik kesimpulan secara induktif, yaitu dari hal yang bersifat khusus menuju ke hal yang bersifat umum, sehingga memungkinkan menghasilkan kesimpulan akhir yang memadai.

\section{Hasil Penelitian dan Pembahasan}

Undang-undang Nomor 28 Tahun 2009 merupakan peraturan yang memuat pajak daerah dan retribusi daerah, di dalamnya terdapat empat jenis pajak baru yang diberikan

\footnotetext{
1990, hlm. 52.

${ }^{6}$ Ronny Hanitijo Soemitro, Metode Penelitian Hukum dan Jurimetri, Ghalia Indonesia, Jakarta,
} 
wewenang sepenuhnya kepada daerah yaitu Pajak Bumi dan Bangunan Perdesaan dan Perkotaan (PBB P2), Bea Perolehan Hak atas Tanah dan Bangunan (BPHTB) yang sebelumnya menjadi wewenang pusat, Pajak Sarang Burung Walet sebagai pajak Kabupaten/Kota serta Pajak Rokok yang merupakan pajak baru bagi Propinsi. Disamping itu juga terdapat empat jenis retribusi baru bagi daerah yaitu Retribusi Pelayanan Tera Ulang, Retribsui Pendidikan, Retribusi Pengendalian Menara Telekomunikasi, dan Retribusi Izin Usaha Perikanan.

\section{Pengertian Pajak}

Pajak adalah iuran kepada negara (yang dapat dipaksakan), yang terhutang oleh yang wajib membayarnya menurut peraturan-peraturan dengan tidak mendapat prestasi kembali, yang langsung dapat ditunjuk, dan yang gunanya untuk membiayai pengeluaran-pengeluaran umum berhubungan dengan tugas Negara untuk menyelenggarakan pemerintahan. ${ }^{7}$

Ada banyak definisi yang diberikan oleh para sarjana, salah satu definisi dari pajak menurut P.J.A. Adriani : "Pajak adalah iuran kepada negara (yang dapat dipaksakan), yang terhutang oleh yang wajib membayarnya menurut peraturan-peraturan dengan tidak mendapat prestasi kembali, yang langsung dapat ditunjuk, dan yang gunanya untuk membiayai pengeluaran-pengeluaran umum berhubungan dengan tugas Negara untuk menyelenggarakan pemerintahan". ${ }^{8}$ (R. Santoso Brotodiharjo, Pengantar Ilmu Hukum Pajak, Cet. 3, Bandung: PT. Eresco Bandung, 1987, hlm 2) Sedangkan menurut Fieldman adalah prestasi yang dipaksakan sepihak oleh dan terhutang kepada penguasa, (menurut norma-norma yang ditetapkannya secara umum), tanpa adanya kontra-prestasi, dan semata-mata digunakan untuk menutup pengeluaranpengeluaran umum. ${ }^{9}$

Dalam pelaksanaannya, pemungutan pajak harus memperhatikan asas-asas pemungutan pajak yaitu : ${ }^{10}$

a. Asas Keadilan.

Keadilan merupakan tujuan dari hukum pajak, oleh karenanya pemungutan pajak harus berdasarkan asas keadilan.

b. Asas Yuridis. 1987, hlm. 2 .

${ }^{7}$ R. Santoso Brotodiharjo, Pengantar Ilmu Hukum Pajak, Cet. 3, PT. Eresco Bandung, Bandung,

${ }^{8}$ Ibid.

${ }^{9}$ Waluyo dan Ilyas, Perpajakan Indonesia Edisi ke 4, Salemba Empat, Jakarta, 2002, hlm. 4.

${ }^{10}$ Mardiasmo, Perpajakan Edisi Revisi, ANDI, Yogyakarta, 2000, hlm.3 
Asas yuridis ini juga berasal dari asas-asas yang dikemukakan oleh Adam Smith, ${ }^{11}$ yaitu asas certainty yang menekankan pentingnya kepastian mengenai pemungutan pajak, yaitu kepastian mengenai subyek pajak dan obyek pajak serta kepastian mengenai tata cara pemungutannya. Dalam asas ini seperti juga halnya asas certainty, pemungutan pajaknya juga harus terdapat jaminan hukum yang memberikan perlindungan terhadap keadilan secara tegas, baik untuk warga maupun untuk negaranya.

c. Asas Ekonomis

Dalam pemungutan pajak selain mernpunyai fungsi budgeter, pajak juga berfungsi sebagai alat untuk menentukan politik perekonomian. Untuk itu dalam pelaksanaannya diharapkan tidak mengganggu kehidupan ekonomis dari wajib pajak.

d. Asas Finansial

Pada asas terakhir ini dimaksudkan bahwa dalam pemungutan dan pengenaan pajak diusahakan menggunakan biaya-biaya yang sekecil dan sehemat mungkin dan mencukupi untuk pengeluaran negara. Artinya bahwa untuk pengeluaran dan pemungutan harus sebanding dengan penerimaan yang negara terima.

Sedangkan sistem pelaksanaan pemungutan pajak yang dikenal adalah $:^{12}$

1. Official Assessment System, yaitu suatu sistem pemungutan pajak dimana wewenang untuk menentukan besarnya pajak yang terutang oleh seseorang berada pada Pemungut Pajak (Fiskus). Dalam sistem ini masyarakat Wajib Pajak bersifat pasif menunggu ketetapan dari Aparatur Pajak atau Pemungut Pajak.

2. Self Assessment System, yaitu suatu sistem pemungutan pajak yang memberikan wewenang kepada Wajib Pajak untuk menentukan sendiri besarnya pajak yang terutang.

3. With Holding System, yaitu suatu sistem pemungutan pajak yang memberi wewenang kepada pihak ketiga (bukan fiskus dan bukan Wajib Pajak yang bersangkutan).untuk menentukan besarnya pajak yang terhutang oleh Wajib Pajak. Contoh pihak ketiga yang dimaksud dalam sistem ini misalnya: konsultan pajak, akuntan publik, Wajib Pungut atau Wajib Potong dan sebagainya.

Dasar hukum penerapan pemungutan pajak di Indonesia adalah ketentuan yang terdapat dalam Undang-Undang Dasar 1945 Pasal 23 huruf A amandemen ketiga yang berbunyi : Pajak dan pungutan lain yang bersifat memaksa untuk keperluan negara diatur dengan undang-undang.

\section{Pengertian Bea Perolehan Hak Atas Tanah dan Bangunan (BPHTB).}

\footnotetext{
${ }^{11}$ H. Rochmat Soemitro dan Dewi Kania Sugiharti, Asas dan Dasar Perpajakan 1, ed. 2, cet. 2, PT Refika Aditama, Bandung, 2010, hlm. 21.

${ }^{12}$ Munawir, S. Perpajakan. Ed. 4. Cet. 1, Liberty, Yogyakarta, 1992, hlm. 44-45.
} 
BPHTB adalah Pajak yang dikenakan atas perolehan hak atas tanah dan atau bangunan. BPHTB dikenakan kepada Pembeli atau pihak yang memperoleh hak atas tanah. Perolehan hak atas tanah dan atau bangunan secara formal dapat diartikan sebagai perbuatan atau peristiwa hukum yang mengakibatkan diperolehnya hak atas tanah dan atau bangunan oleh orang pribadi atau badan.

Bea Perolehan Hak Atas Tanah dan Bangunan (BPHTB) merupakan salah satu pajak obyektif atau pajak kebendaan dimana pajak terutang didasarkan pertama-tama pada apa yang menjadi obyek pajak baru kemudian memperhatikan siapa yang menjadi subyek pajak. $^{13}$

Dasar hukum pemungutan atas Bea Perolehan Hak Atas Tanah dan Bangunan (BPHTB) adalah Undang-undang Nomor 28 Tahun 2009 tentang Pajak Daerah dan Retribusi Daerah yang diundangkan pada tanggal 15 September 2009.

Berdasarkan ketentuan Pasal 85 ayat (1) Undang-undang Nomor 28 Tahun 2009 tentang Pajak Daerah dan Retribusi Daerah, dijelaskan yang menjadi obyek pajak BPHTB adalah perolehan hak atas tanah dan/atau bangunan. Perolehan hak atas tanah dan/atau bangunan menurut Pasal 1 ayat 42 Undang-undang Nomor 28 Tahun 2009 adalah perbuatan atau peristiwa hukum yang mengakibatkan diperolehnya hak atas tanah dan/atau bangunan oleh orang pribadi atau Badan. Pasal 85 ayat 2 Undang-undang Nomor 28 Tahun 2009 menyebutkan perolehan tersebut meliputi :

a. Pemindahan hak :

1. Jual beli

2. Tukar-menukar;

3. Hibah;

4. Hibah Wasiat;

5. Waris;

6. Pemasukan dalam perseroan atau badan hukum lainnya;

7. Pemisahan hak yang mengakibatkan Peralihan;

8. Penunjukan pembeli dalam lelang;

9. Pelaksanaan putusan hakim yang mempunyai kekuatan hukum tetap;

10. Penggabungan usaha;

11. Peleburan usaha;

12. Pemekaran usaha;

13. Hadiah.

b. Pemberian hak baru

1. Kelanjutan pelepasan hak; atau

2. Di luar pelepasan hak.

\footnotetext{
${ }^{13}$ Marihot Pahala Siahaan, Op.cit, hlm. 59.
} 


\section{Peralihan Hak Atas Tanah dan Bangunan karena jual beli.}

Pasal 1 ayat 42 Undang-undang Nomor 28 Tahun 2009 tentang Pajak Daerah dan Retribusi Daerah menyebutkan :

"Perolehan Hak atas Tanah dan/atau Bangunan adalah perbuatan atau peristiwa hukum yang mengakibatkan diperolehnya hak atas tanah dan/atau bangunan oleh orang pribadi atau Badan."

Perolehan hak atas tanah dan bangunan terjadi karena adanya peralihan hak yang meliputi peristiwa hukum dan perbuatan hukum yang terjadi antara orang atau badan hukum sebagai subyek hukum yang oleh Undang-undang dan peraturan hukum yang berlaku diberikan kewenangan untuk memiliki hak atas tanah dan bangunan, dan menurut hukum peralihan hak terjadi karena dua hal, yaitu hak beralih dan hak dialihkan.

Setiap peralihan hak atas tanah wajib didaftarkan kepada kantor Pertanahan untuk menjamin kepastian dan perlindungan hukum bagi pemegang haknya. Dalam pendaftaran hak atas tanahnya memerlukan peranan Pejabat Pembuat Akta Tanah (PPAT). Pasal 37 ayat (1) Peraturan Pemerintah R.I. Nomor 24 Tahun 1997 menyebutkan bahwa setiap peralihan hak atas tanah dan hak milik atas satuan rumah susun melalui jual beli, tukar menukar, hibah, pemasukan dalam perusahaan dan perbuatan hukum pemindahan hak lainnya, kecuali pemindahan hak melalui lelang hanya dapat didaftarkan jika dibuktikan dengan akta yang dibuat oleh PPAT yang berwenang menurut ketentuan peraturan perundang-undangan yang berlaku.

Jabatan PPAT menurut Peraturan Pemerintah R.I. Nomor 37 Tahun 1998 pada dasarnya mempunyai peranan yang sangat penting dalam pemeliharaan data pendaftaran tanah, yaitu dengan membuat alat bukti mengenai telah terjadinya perbuatan hukum mengenai sebidang tanah tertentu yang kemudian dijadikan dasar untuk mendaftar perubahan data yuridis yang diakibatkan oleh perbuatan hukum itu.

Sebagai ketentuan formalnya, PPAT membuat akta dari perbuatan hukum peralihan hak karena jual beli tersebut dengan bentuk, isi dan cara pembuatannya sebagaimana yang diatur dalam Peraturan Pemerintah Nomor 24 tahun 1997, Peraturan Pemerintah Nomor 37 tahun 1998 jo Peraturan Kepala Badan Pertanahan Nasional Nomor 1 tahun 2006 dan Peraturan Menteri Negara Agraria/Kepala BPN Nomor 3 tahun 1997.

Dalam proses administrasi penandatanganan sebuah akta jual beli antara penjual dan pembeli dihadapan Pejabat Pembuat Akta Tanah (PPAT), PPAT mewajibkan kepada Wajib Pajak untuk menyerahkan bukti pembayaran atau pelunasan pajak BPHTB yang terhutang 
melalui form Surat Setoran Pajak Daerah Bea Perolehan Hak atas Tanah dan Bangunan (SSPD BPHTB) dan telah tervalidasi oleh pihak DPKAD.

\section{Pemungutan Bea Perolehan Hak Atas Tanah dan Bangunan (BPHTB).}

Tujuan terbesar pengalihan BPHTB berdasarkan Undang-undang Nomor 28 Tahun 2009 tidak lain adalah untuk meningkatkan local taxing power Kabupaten dan Kota yang selama ini belum berjalan secara maksimal, walaupun lokalitas objek Pajak Bumi dan Bangunan Perdesaan dan Perkotaan dan BPHTB berlokasi di daerah kabupaten dan kota. Pengalihan pemungutan BPHTB dari Pusat ke Daerah tidak hanya sebatas pemungutan atau penagihan saja, melainkan juga pada pendataan, penilaian, penetapan, pelayanan yang menyeluruh disamping pengadministrasian yang harus dilaksanakan daerah.

Kepala Daerah dalam menyelenggarakan keseluruhan pengelolaan keuangan daerah, membentuk Satuan Kerja Pengelola Keuangan Daerah (SKPKD). SKPKD adalah perangkat daerah pada pemerintah daerah selaku pengguna anggaran/pengguna barang, yang juga melaksanakan pengelolaan keuangan daerah. Selanjutnya, Pejabat Pengelola Keuangan Daerah (PPKD) adalah kepala satuan kerja pengelola keuangan daerah yang selanjutnya disebut dengan kepala SKPKD yang mempunyai tugas melaksanakan pengelolaan APBD dan bertindak sebagai Bendahara Umum Daerah.

Bentuk penerimaan pajak daerah salah satunya berasal dari Bea Perolehan Atas Hak Atas Tanah Dan Bangunan (BPHTB). Transaksi paling besar yang menghasilkan pemasukan dari BPHTB adalah transaksi peralihan hak atas dan bangunan terutama transaksi jual beli hak atas tanah dan bangunan, sehingga dengan demikian tidak berlebihan bila dikatakan peran Notaris selaku PPAT sangat berarti dalam pencapaian penerimaan target BPHTB dan mengamankan penerimaan BPHTB dari transaksi peralihan hak atas tanah dan bangunan.

Saat pajak terutang atas perolehan hak atas tanah dan atau bangunan karena jual beli adalah sejak tanggal dibuat dan ditandatanganinya akta jual beli, hal ini sesuai dengan ketentuan Pasal 90 ayat 1 huruf a Undang-undang Nomor 28 Tahun 2009 tentang Pajak Daerah dan Retribusi Daerah.

Dalam proses administrasi pendaftaran peralihan hak karena jual beli di Kantor Pertanahan Kabupaten/Kota, Kepala Kantor Badan Pertanahan Nasional akan meminta bukti pelunasan atau pembayaran BPHTB kepada Wajib Pajak sebelum diterbitkannya sebuah sertifikat tanah. Bukti pelunasan atau pembayaran itu sendiri juga harus telah 
ditandatangani dan di validasi oleh pihak Dinas Pengelolaan Pendapatan dan Keuangan Daerah.

\section{Penutup}

Berdasarkan hasil penelitian dan pembahasan mengenai pengenaan Bea Perolehan Hak atas Tanah dan Bangunan dalam proses jual beli tanah dan bangunan di Kabupaten Kebumen dapat diperoleh suatu kesimpulan sebagai berikut: pertama, pelaksanaan pemungutan Bea Perolehan Hak atas Tanah dan Bangunan dalam proses jual beli tanah dan bangunan di Kabupaten Kebumen dilaksanakan dengan sistem self assessment yang memberikan kepercayaan kepada Wajib Pajak untuk menghitung, memperhitungkan, membayar sendiri pajak yang terhutang dengan menggunakan formulir SSPD BPHTB yang diperoleh oleh Wajib Pajak dari DPPKAD Kabupaten Kebumen. Penentuan nilai jual atas tanah dalam BPHTB adalah berdasarkan Undang-undang Nomor 28 Tahun 2009 dan Peraturan Daerah Kabupaten Kebumen Nomor 18 Tahun 2010 dimana nilai jual atas tanah dalam BPHTB adalah berdasarkan nilai transaksi yang terjadi atas jual beli sesuai dengan kwitansi atau sebagaimana tercantum dalam Akta Jual Beli atau sesuai bukti otentik lainnya yang dapat dipertanggungjawabkan oleh Wajib Pajak. Kedua, kendala-Kendala yang timbul dalam pelaksanaan pemungutan Bea Perolehan Hak atas Tanah dan Bangunan diantaranya kurangnya sosialisasi mengenai tata cara pembayaran BPHTB kepada masyarakat, tingkat kesadaran masyarakat yang masih sangat terbatas pada kewajiban pembayaran pajak, ketidakjujuran wajib pajak dalam mencantumkan nilai transaksi jual beli pada akta jual beli, kurangnya jumlah personil yang ahli di DPPKAD serta kendala yang timbul dari pihak bank/kantor kas daerah yang telah ditunjuk untuk menerima pembayaran BPHTB dapat diselesaikan dengan upaya-upaya diantaranya dengan melaksanakan sosialisasi mengenai tata cara pembayaran BPHTB kepada masyarakat agar meningkatkan kesadaran masyarakat untuk membayar pajak, bekerja sama dengan Notaris/PPAT dalam menetapkan aturan pembayaran BPHTB yang sesuai dengan peraturan perundang-undangan serta menetapkan suatu sanksi terhadap penyelewengan/ pelanggaran pembayaran BPHTB. Kegiatan verifikasi dan validasi oleh DPPKAD Kabupaten Kebumen menyebabkan lemahnya kepastian hukum terhadap akta jual beli. Lemahnya kepastian hukum tersebut disebabkan karena adanya proses verifikasi dan validasi yang terkadang dapat menganulir harga transaksi dalam akta jual beli yang sudah menjadi kesepakatan pihak penjual dan pembeli. Kewajiban wajib pajak untuk melakukan verifikasi dan validasi terhadap NPOP BPHTB 
juga menyebabkan terhambatnya pelaksanaan penandatanganan akta jual beli dan pendaftaran peralihan hak atas tanahnya.

Berdasarkan kesimpulan sebagaimana tersebut di atas maka ada beberapa hal yang penulis sarankan dalam upaya pelaksanaan pengenaan Bea Perolehan Hak atas Tanah dan Bangunan dalam proses jual beli tanah dan bangunan di Kabupaten Kebumen: pertama, Pemerintah Daerah seharusnya memperhatikan beberapa aspek dalam menerbitkan peraturan-peraturan atau kebijakan-kebijakan tentang Bea Perolehan Hak atas Tanah dan Bangunan, aspek-aspek tersebut diantaranya kondisi objek pajak dan kondisi masyarakat agar aturan-aturan atau kebijakan-kebijakan tersebut bermanfaat dan tidak memberatkan kepada masyarakat. Kedua, Dinas Pendapatan Pengelolaan Keuangan dan Aset Daerah (DPPKAD) Kabupaten Kebumen dalam penentuan kebijakan pemungutan Bea Perolehan Hak atas Tanah dan Bangunan harus bekerja sama dengan Notaris/PPAT maupun Kantor Pertanahan setempat. Ketiga, Dinas Pendapatan Pengelolaan Keuangan dan Aset Daerah (DPPKAD) Kabupaten Kebumen harus melakukan sosialisasi mengenai pembayaran Bea Perolehan Hak atas Tanah dan Bangunan kepada masyarakat. Hal ini diperlukan untuk meningkatkan kesadaran masyarakat dalam membayar pajak atas transaksi jual beli yang telah mereka lakukan. 


\section{Daftar Pustaka}

\section{Buku dan Literatur}

Brotodiharjo, R. Santoso, Pengantar Ilmu Hukum Pajak, Cet. 3, PT. Eresco Bandung, Bandung, 1987

Hanitijo Soemitro, Ronny, Metodologi Penelitian Hukum dan Jurimetri Ghalia Indonesia, Jakarta, 1990

Ilyas, Wiryawan B. dan Richard Burton, Hukum Pajak. Ed. 1, Salemba Empat, Jakarta, 2001

Ismail, Tjip, Pengaturan Pajak Daerah di Indonesia, Penerbit Departemen Keuangan Republik Indonesia Badan Pengkajian Ekonomi Keuangan dan Kerjasama Internasional Pusat Evaluasi Pajak dan Retribusi Daerah, Jakarta, 2005, hal. 12

Kartodirdjo, Sartono, Metodologi Penelitian Masyarakat,Gramedia, Jakarta, 1983

Lubis, Solly, Politik Hukum dan Kebijakan Publik, Mandar Maju, Bandung, 2014.

Mamudji, Sri, Metode Penelitian dan Penelusuran Hukum, Raja Grafindo Persada, Jakarta, 2005

Mardiasmo, Perpajakan Edisi Revisi, ANDI, Yogyakarta, 2000

Muhammad, Abdulkadir, Hukum dan Penelitian Hukum , Citra Aditya Bakti , Bandung, 2004.

Munawir, S. Perpajakan. Ed. 4. Cet. 1, Liberty, Yogyakarta, 1992

Nurmana, Safri, Pengantar Perpajakan, Obor Indonesia, Jakarta, 2003

Narbuko, Cholid dan H. Abu Achmadi, Metodologi Penelitian, PT. Bumi Aksara, Jakarta, 2002

Pahala Siahaan, Marihot, Utang Pajak, Pemenuhan Kewajiban dan Penagihan Pajak dengan Surat Paksa, cet. 1, Raja Grafindo Persada, Jakarta, 2004

, Bea Perolehan Hak atas Tanah dan Bangunan, Teori dan Praktik, Edisi Revisi, Rajawali Pers, Jakarta, 2003

Rusjdi, Muhammad, PBB, BPHTB, \& Bea Materai, PT Indeks, Jakarta, 2005.

Soekanto, Soerjono, Pengantar Penelitian Hukum, Universitas Indonesia Press arta, 2007. , Sosiologi Suatu rengantar, Raja Gravindo Persada, Jakarta, 2001. dan Sri Mamudji, Penelitian Hukum Normatif Suatu Tinjauan Singkat, Raja Grafindo Persada, Jakarta, 2003.

Soemitro, H. Rochmat dan Dewi Kania Sugiharti, Asas dan Dasar Perpajakan 1, ed. 2, cet. 2, PT Refika Aditama, Bandung, 2010

Sunggono, Bambang, Metodologi Penelitian Hukum, PT Raja Grafindo Persada, Jakarta, 2003

Waluyo dan Ilyas, Perpajakan Indonesia Edisi ke 4, Salemba Empat, Jakarta, 2002.

Winarno, Budi, Kebijakan Publik Teori dan Proses, Media Pressindo, Yogyakarta, 2007. 


\section{Peraturan Perundang-undangan}

Undang-Undang Dasar Republik Indonesia Tahun 1945.

Undang-Undang Nomor 5 Tahun 1960 tentang Peraturan Dasar Pokok-Pokok Agraria.

Undang-Undang Republik Indonesia Nomor 6 Tahun 1983, sebagaimana telah diubah dengan Undang-Undang Nomor 9 Tahun 1994, Undang-Undang Nomor 16 Tahun 2000, Undang-Undang Nomor 28 Tahun 2007, terakhir dengan Peraturan Pemerintah Pengganti Undang-Undang Republik Indonesia Nomor 5 Tahun 2008 tentang Perubahan Keempat atas Undang-Undang Nomor 6 Tahun 1983 tentang Ketentuan Umum dan Tata Cara Perpajakan.

Undang-Undang Republik Indonesia Nomor 19 Tahun 1997, sebagaimana telah diubah dengan Undang-Undang Nomor 19 Tahun 2000 tentang Penagihan Pajak dengan Surat Paksa.

Undang-Undang Republik Indonesia Nomor 21 Tahun 1997, sebagaimana telah diubah dengan Undang-Undang Nomor 20 Tahun 2000 tentang Bea Perolehan Hak atas Tanah dan Bangunan.

Undang-Undang Republik Indonesia Nomor 28 Tahun 2009 tentang Pajak Daerah dan Retribusi Daerah.

Peraturan Daerah Kabupaten Kebumen Nomor 18 Tahun 2010 tentang Bea Perolehan Hak atas Tanah dan Bangunan.

\section{Lain-lain}

Kementerian Keuangan Republik Indonesia, Direktorat Jenderal Perimbangan Keuangan; Tinjauan Pelaksanaan Pengalihan Bea Perolehan Hak atas Tanah dan Bangunan (BPHTB) Menjadi Pajak Daerah, Jakarta, 2011 